\title{
PEMANFAATAN DAUN KELOR SEBAGAI BAHAN DASAR PRODUK OLAHAN MAKANAN DI KELURAHAN KAMBANIRU
}

\author{
Junaedin Wadu'), Anggreni Madik Linda'), Elfis Umbu Katongu Retang1), Elsa Christin Saragih'1) \\ ${ }^{1)}$ Program Studi Agribisnis, Fakultas Sains dan Teknologi, Universitas Kristen Wira Wacana Sumba, \\ Nusa Tenggara Timur, Indonesia \\ Corresponding author : Junaedin Wadu \\ Email: junawadu@unkriswina.ac.id
}

Diterima 04 Maret 2021, Direvisi 17 Maret 2021, Disetujui 17 Maret 2021

\begin{abstract}
ABSTRAK
Kelor menjadi salah satu tanaman yang mempunyai kandungan gizi yang tinggi dan daunnya dapat dimanfaatkan sebagai salah satu bahan dasar pengolahan makanan ataupun minuman. Program pengabdian masyarakat dilakukan pada kelompok tani le Hari 1 di Kelurahan Kambaniru Kecamatan Kambera Kabupaten Sumba Timur. Metode yang digunakan pada pengabdian ini yaitu metode penyuluhan dengan memberikan materi terkait pengenalan produk kelor dan nilai gizinya, serta memberikan pelatihan langsung pembuatan pudding dan ice cream kelor. Anggota kelompok tani le hari 1 didominasi oleh wanita yang mempunyai potensi dalam pengolahan produk makanan dari daun kelor, karena tersedia pohon kelor di sekitaran rumah para anggota kelompok. Hasil dari Pengabdian Kepada Masyarakat ini adalah kelompok tani mempunyai ketertarikan dalam mengenal produk olahan kelor yang mempunyai nilai ekonomis yang baik.
\end{abstract}

Kata kunci : kelor; bahan dasar; kelompok tani le hari 1

\begin{abstract}
Moringa is a plant that has a high nutritional content and its leaves can be used as one of the basic ingredients for food or beverage processing. The community service program was carried out at the le Day 1 farmer group in Kambaniru Village, Kambera District, East Sumba Regency. The method used in this service is the extension method by providing material related to the introduction of Moringa product and its nutritional value, as well as providing direct training in making Moringa pudding and ice cream. The le day 1 farmer group members are dominated by women who have the potential in processing food products from Moringa leaves, because there is a Moringa tree around the house of the group members. The result of this Community Service is that farmer groups have an interest in getting to know Moringa processed products that have good economic value.
\end{abstract}

Keywords: moringa; basic material; le farmer group day 1

\section{PENDAHULUAN}

Kelor (Moringa oleifera) merupakan tanaman yang mempunyai kandungan gizi yang tinggi, (Kristina \& Siti, 2014) mengungkapkan daun kelor kaya akan nutrisi seperti beta karoten, vitamin C, besi, dan potassium, sehingga daun kelor dapat digunakan sebagai pemenuhan gizi harian keluarga, karana murah dan mudah dikembangkan. (Hamzah \& Yusuf, 2019) menyatakan kelor mudah didapat dan tanpa mengeluarkan biaya yang tinggi mampu memulihkan malnutrisi pada anak-anak secara cepat. Sedangkan Pengembangan tanaman kelor dapat dilakukan dengan batang stek dan biji yang ditanami secara langsung di lahan.

$$
\text { Masyarakat pada umumnya }
$$

mengkonsumsi kelor sebatas pelengkap dalam masakan sehari-hari dengan proses yang sederhana seperti direbus atau ditumis sebagai sayur. (Purba, 2020) mengungkapkan walaupun kelor dikenal sebagai tumbuhan yang sangat beranfaat, namun masih banyak masyarakat Indonesia yang belum memanfaatkannya. Padahal sebenarnya daun kelor dapat diolah menjadi bahan setengah jadi yaitu bubuk kelor, yang kemudian dapat dolah dalam berbagai varian makanan dan minuman yang mempunyai nilai ekonomi yang tinggi seperti puding kelor, es krim kelor, teh kelor, stik kelor, dan sebagainya. (Rohmawati et al., 2019) mengungkapkan pembuatan es krim dengan menggunakan tepung menggunakan tepung kelor menjadi salah satu alternatif usaha diversifikasi pengolahan, serta es krim merupakan salah satu solusi pilihan makanan bagi masayrakat.

Seiring dengan bertambahnya jumlah penduduk dan persaingan dunia usaha kuliner, 
masyarakat diharuskan mampu berinovasi dalam menciptakan berbagai produk-produk makanan yang mempunyai nilai ekonomi dan nilai gizi yang baik agar dapat diterima serta disukai oleh konsumen. Oleh sebab itu kelor dapat menjadi salah satu alternatif yang tepat untuk dimanfaatkan sebagai bahan dasar dalam pengolahan makanan maupun minuman. Program pengabdian kepada masyarakat (PKM) kali ini memperkenalkan kepada masyarakat melalui kelompok tani tentang manfaat dan kandungan gizi kelor yang tinggi, yang dapat dimanfaatkan sebagai bahan dasar pengolahan makanan. Seperti penelitian (Dewi, 2018) penambahan tepung daun kelor mempunyai pengaruh terhadap sifat organoleptik, kadar prokosimat, dan kadar Fe. (Mazidah et al., 2018) mengungkapkan substitusi tepung daun kelor menjadi salah satu alternatif mengurangi penggunaan tepung terigu. Lebih lanjut penambahan ekstrak daun kelor untuk pembuatan mie basah bersubstitusi menunjukkan perbedaaan yang nyata terhadap organoleptic dan peningkatan protein seiring dengan penigkatan penambahan ekstrak daun kelor (Khasanah \& Astuti, 2019). Selain itu kegiatan PKM ini juga memberikan pelatihan kepada masayarakat tentang pemanfaan daun kelor sebagai bahan dasar dalam pembuatan makanan dan minuman, sehingga masyarakat mempunyai gambaran tentang produk-produk yang dapat dibuat dengan bahan dasar daun kelor.

\section{METODE}

Kegiatan Pengabdian Masyarakat dilakukan pada Kelompok tani le Hari 1 di Kelurahan Kambaniru, Kecamatan Kambera, Kabupaten Sumba Timur. peserta yang terlibat pada kegiatan ini yaitu terdiri dari ketua kelompok tani dan anggota kelompok tani yang didominasi oleh wanita. Adapun pelaksanaan Pengabdian Masyarakat ini telah dilaksanakan pada bulan Juni 2020.

Pelaksanaan kegiatan Pengabdian Kepada Masyarakat kali ini terbagi dalam dua tahapan yaitu penyuluhan dan pelatihan.

\section{Penyuluhan}

Penyuluhan yang disampaikan kepada kelompok tani le Hari yaitu penjelasan terkait manfaat tanaman kelor dan potensi daun kelor untuk dijadikan produk makanan. Selanjutnya dibuka sesi diskusi dan tanya jawab terkait materi yang disampaikan agar para anggota kelompok lebih memahami materi yang diberikan. Melalui pennyuluhan ini diharapkan para anggota kelompok dapat memahami dan memanfaatkan daun kelor yang mempunyai nilai gizi yang tinggi dan potensial untuk diolah menjadi berbagai produk makanan dan minuman.

\section{Pelatihan}

Pelatihan yang diberikan kepada anggota kelompok tani dengan mendemonstasikan secara langsung pembuatan pudding dan ice cream kelor. Adapun bahan dan alat yang dinakan sebagai berikut :

Pudding kelor: bubuk agar-agar 2 bungkus, gula pasir 8 sendok, air $500 \mathrm{ml}$, susu UHT 500 $\mathrm{ml}$, santan $500 \mathrm{ml}$, daun kelor segar.

Ice cream kelor: santan cair $1 \mathrm{~L}$, susu kental manis $200 \mathrm{ml}$, gula pasir 8 sendok makan, tepung maizena 4 sendok makan, ekstrak daun kelor $400 \mathrm{ml}$, dua sendok makan SP, garam

Alat yang digunakan: Kompor, sutel, saringan, wajan, wadah untuk pudding, blender, mixer

\section{HASIL DAN PEMBAHASAN Penyuluhan}

Pemilihan tempat PKM di Kelurahan Kambaniru, Kecamatan Kambera Kabupaten Sumba Timur diawali dengan survei awal yang dilakukan oleh dosen program studi untuk mengetahui potensi dan permasalahan yang terjadi di kelompok tani. Adapun hasil survei sebagai berikut: Kelompok Tani Mitra Sejahterah dan Kelompok Tani le Hari sangat antusias dengan program pelatihan yang akan dilaksanakan, karena kedua anggota kelompok tani tersebut sudah melakukan budidaya kelor tapi mereka belum memanfaatkan dengan baik atau belum melakukan inovasi-inovasi produk dari dalam kelor yang dapat menambah nilai jual dari daun tersebut. Selanjunya melakukan perijinan kepada Lurah Kambaniru untuk melakukan kegiatan penyuluhan dan pelatihan. Penyuluhan yang dilakukan dengan memberikan beberapa materi kepada anggota kelompok tani, yaitu tentang budidaya kelor, manfaat dan nilai gizi kelor, serta potensi kelor untuk pengolahan/pengenalan produk olahan kelor. Kegiatan penyuluhan dapat dilihat pada Gambar 1 di bawah ini.

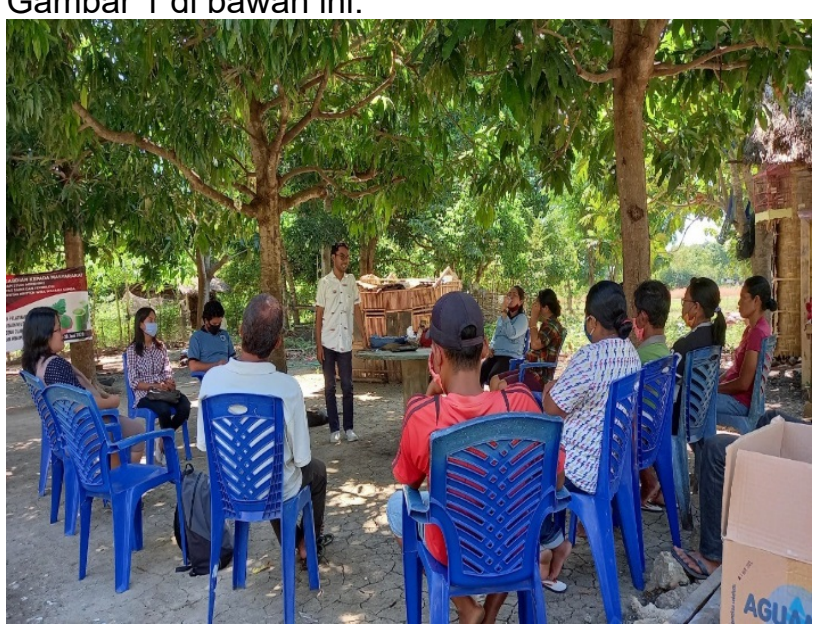

Gambar 1. Kegiatan Penyuluhan 


\section{Pelatihan}

Kegiatan pelatihan dilakukan dengan memberikan praktek langsung kepada pengurus dan anggota kelompok. Tahap awal yang dilakukan untuk mempersiapkan bahan dasar daun kelor untuk dipetik, direndam dan dicuci guna menghilangkan kotoran dari daun. Adapun tahapan kegiatan pelatihan sebagai berikut:

\section{Pembuatan Puding Kelor}

Persiapan bahan dan alat

Adapun bahan-bahan yang digunakan dalam pembuatan pudding: kelor yaitu, daun kelor segar, bubuk agar-agar, susu UHT, santan, dan susu kental manis. Sedangkan alat yang digunakan dalam pembuatan pudding kelor yaitu, blender, wajan, sutel, saringan, dan kompor.

Proses Pembuatan

a. Cuci bersih daun kelor lalu direbus, kemudian angkat dan sisihkan daun kelor dari air rebusan.

b. Daun kelor yang sudah direbus ditambahkan air $500 \mathrm{~mL}$ lalu dihaluskan dengan menggunakan blender dan kemudian di saring.

c. Campurkan ekstrak daun kelor, nutrijel, gula, susu, santan dan susu UHT 500 mL kemudian direbus sampai mendidih.

d. Kemudian adonan dituang ke masingmasing wadah yang sudah disiapkan.

e. Tunggu beberapa saat sampai dingin dan dimasukkan ke kulkas.

f. Puding daun kelor siap disajikan.

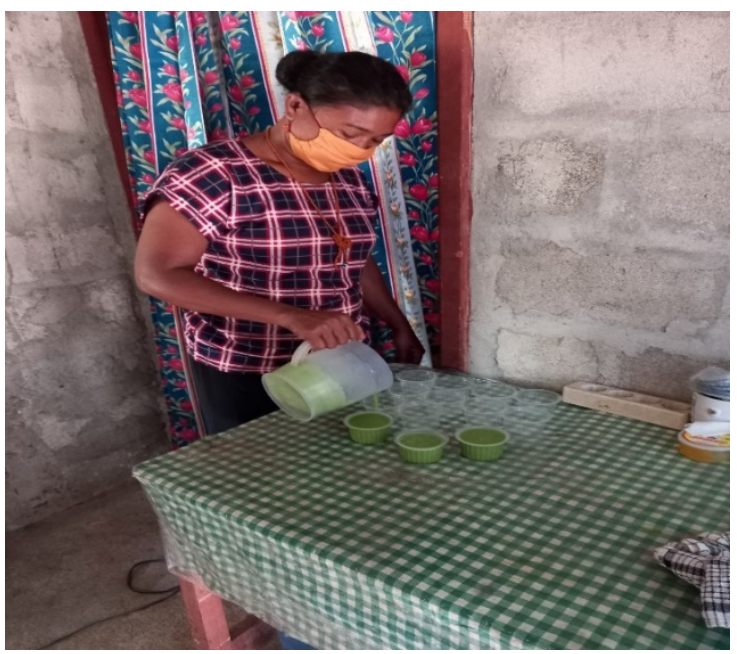

Gambar 2. Proses pembuatan pudding kelor

Gambar 2, merupakan kegiatan pembuatan pudding kelor yang diikuti oleh ibuibu kelompok tani le Hari 1 dan dipandu langsung oleh dosen.
2. Pembuatan Ice cream kelor

Persiapan bahan dan alat

Adapaun bahan yang digunakan dalam pembuatan ice cream kelor adalah sebagai berikut: kelor segar, santan, gula pasir, tepung maizena, pengemulsi, dan garam, sedangkan alat yang digunaka dalam pembuatan ice cream kelor adalah: mixer, blender, wajan, wisk pengaduk, dan kompor.

Proses Pembuatan

a. Cuci bersih daun kelor lalu blender dengan menambahkan air $400 \mathrm{~mL}$ dan disaring.

b. Ekstrak daun kelor dimasukan kedalam wajan dan tambahkan tepung maizena, gula pasir, garam, santan kelapa, dan susu kental manis.

c. Kemudian diaduk hingga merata dengan api sedang.

d. Setelah itu adonan dimasak sampai mendidih dan mengental

e. Setelah itu di masukkan ke dalam loyang atau panci dan didinginkan.

f. Setelah dingin, adonan tersebut dimasukkan kedalam freezer sampai setengah beku selama 4 jam.

g. Setelah itu adonan diangkat kemudian dan dikeruk.

h. Masukkan SP dan perasa makanan keadonan kemudian mixer hingga halus

i. Tuang adonan ke dalam masing-masing wadah yang sudah disiapkan lalu masukkan kembali ke freezer hingga membeku.

j. Ice cream siap disajikan.

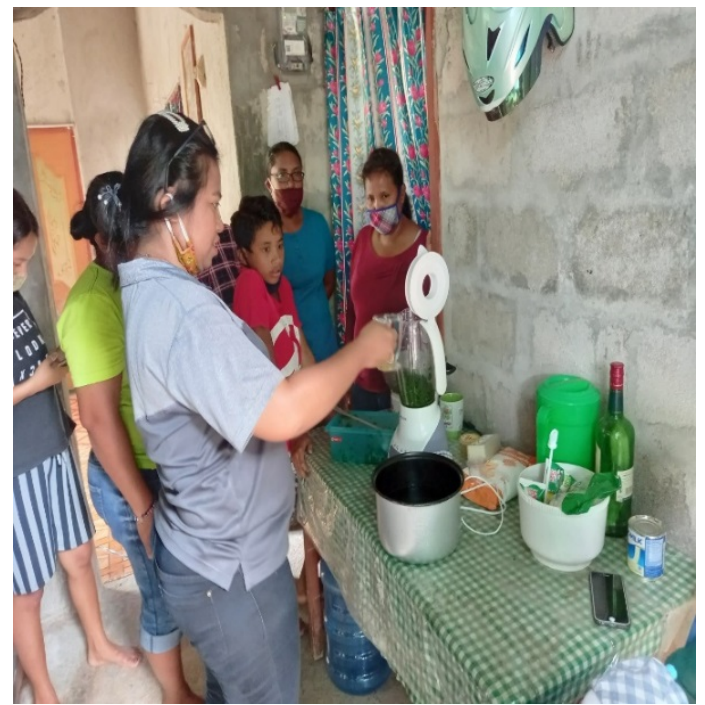

Gambar 3. Pelatihan pembuatan ice cream kelor

Gambar 3, memperlihatkan kegiatan pembuatan ice cream kelor yang diarahakan oleh salah satu dosen dan nampak diperhatikan oleh ibu-ibu kelompok tani dengan seksama. 
Setelah melakukan kegiatan pelatihan, para peserta mempunyai ketertarikan dalam membuat olahan dari kelor karena manarik minat anak-anak untuk mengkonsumsi jajanan buatan sendiri yang sehat dan hieginis. Pelatihan produk pangan fungsional dapat bertujuan untuk meningkatkan ketrampilan masyarakat (Hambakodu et al., 2020).

\section{SIMPULAN DAN SARAN}

Dari hasil pelaksanaan kegiatan ini, maka dapat disimpulkan sebagai berikut :

Pertama, Kelompok tani le Hari 1 Kelurahan Kambaniru Kecamatan Kambera antusias dan memiliki semangat dalam menerima materi penyuluhan. Kedua, pelatihan pembuatan puding kelor dan ice cream kelor yang dilakukan oleh peserta diberikan dengan teknik yang sederhana. Ketiga, bahan dasar daun kelor dapat ditemukan dengan mudah oleh peserta sehingga dapat diaplikasikan oleh peserta. Keempat, perlu adanya evaluasi program pembuatan makanan berbahan dasar kelor untuk kepentingan kewirausahaan yang berpotensi meningkatkan ekonomi peserta.

\section{UCAPAN TERIMAKASIH}

Penulis mengucapkan terimakasih yang sebesar-besarnya kepada Universitas Kristen Wira Wacana Sumba yang telah mendanai kegiatan Pengabdian Kepada Masyarakat tahun 2020.

\section{DAFTAR RUJUKAN}

Dewi, D. P. (2018). Substitusi Tepung Daun Kelor (Moringa oleifera L.) pada Cookies Terhadap Sifat Fisik, Sifat Organoleptik, Kadar Proksimat, dan Kadar Fe. IImu Gizi Indonesia, 1(2), 104-112. https://doi.org/10.35842/ilgi.v1i2.22

Hambakodu, M., Hina Tarapanjang, A., Pati Ranja, E., \& Christine Nara, M. (2020). Pelatihan Pengolahan Virgin Coconut Oil (Vco) Sebagai Minuman Suplemen Pada Masa Pendemi Covid 19 Di Desa Wunga. SELAPARANG Jurnal Pengabdian Masyarakat Berkemajuan, 4(1), 268. https://doi.org/10.31764/jpmb.v4i1.275 6

Hamzah, H., \& Yusuf, N. R. (2019). Analisis Kandungan Zat besi (Fe) Pada Daun Kelor (Moringa oleifera Lam.) Yang Tumbuh dengan Ketinggian Berbeda di Daerah Kota Baubau. Indo. J. Chem. Res., 6(2), 88-93. https://doi.org/10.30598//ijcr.2019.6- has

Khasanah, V., \& Astuti, P. (2019). Pengaruh Penambahan Ekstrak Dau Kelor (Moringa Oleifera) Terhadap Kualitas Inderawi Dan Kandungan Protein Mie Basah Substitusi Tepung Mocaf. Jurnal Kompetensi Teknik, 11(2), 15-21. https://doi.org/10.15294/jkomtek.v11i2. 22499

Kristina, N. N., \& Siti, F. S. (2014). Pemanfaatan tanaman kelor (Moringa oleifera) untuk meningkatkan Produksi Air Susu lbu. Warta Penelitian Dan Pengembangan Tanaman Industri, 20(3), 26-29.

Mazidah, Y. F., Kusumaningrum, I., \& Safitri, D. E. (2018). Penggunaan Tepung Daun Kelor pada Pembuatan Crackers Sumber Kalsium. ARGIPA (Arsip Gizi Dan Pangan), 3(2), 67-79. https://doi.org/10.22236/argipa.v3i2.24 62

Purba, E. C. (2020). Kelor (Moringa oleifera Lam.): Panfaatan Dan Bioaktivitas. ProLife, $\quad 7(1), \quad 1-12$. https://doi.org/10.33541/jpvol6iss2pp1 02

Rohmawati, N., Moelyaningrum, A. D., \& Witcahyo, E. (2019). Es Krim Kelor: Produk Inovasi Sebagai Upaya Pencegahan Stunting Dalam 1000 Hari Pertama Kehidupan ( Hpk ). Randang Tana Jurnal Pengabdian Masyarakat, 2(1), 10-20. http://jurnal.unikastpaulus.ac.id/index.p hp/jrt/article/view/276 